\title{
Sosyal Medya Reklamcılığının Tüketici Satın Alma Davranışı Üzerine Etkisinin Yapısal Eşitlik Modellemesi İle İncelenmesi
}

\author{
Sinem Sargın ${ }^{1 *}$, Burcu Oralhan ${ }^{2}$, Ahmet Serkan Üvenç ${ }^{3}$ \\ ${ }^{1}$ Nuh Naci Yazgan Üniversitesi, İktisadi ve İdari Bilimler Fakültesi, İşletme Bölümü, Kayseri, Türkiye (ORCID: 0000-0002-7504-154X) \\ ${ }^{2}$ Nuh Naci Yazgan Üniversitesi, İktisadi ve İdari Bilimler Fakültesi, İşletme Bölümü, Kayseri, Türkiye (ORCID: 0000-0001-8905-0140) \\ ${ }^{3}$ Nuh Naci Yazgan Üniversitesi, İktisadi ve İdari Bilimler Fakültesi, İşletme Bölümü, Kayseri, Türkiye (ORCID: 0000-0001-6989-0994)
}

(İlk Geliş Tarihi 10 Eylül 2020 ve Kabul Tarihi 8 Kasım 2020)

(DOI: 10.31590/ejosat.793072)

ATIF/REFERENCE: Sargın, S., Oralhan, B. \& Üvenç, A. S. (2020). Sosyal Medya Reklamcılığının Tüketici Satın Alma Davranışı Üzerine Etkisinin Yapısal Eşitlik Modellemesi İle İncelenmesi. Avrupa Bilim ve Teknoloji Dergisi, (20), 632-639.

Öz

Günümüzde mal ve hizmet sağlayıcılar açısından reklam oldukça önemli bir tutundurma faaliyeti haline gelmiştir. Bir reklam kampanyasının başarılı olabilmesi için etkin bir stratejinin ortaya konulması gereklidir. Firmanın geliştirdiği stratejiler ise bazı reklam araçları ile tüketicilere iletilmektedir. Sosyal medya reklamcılı̆̆ı firmaların, hedef pazardaki tüketicilerle, bir mobil cihaz veya ağ aracılı̆̆ıla etkileşimli bir biçimde iletişim ve ilişki kurmasını sağlayan eylemler dizisi olarak tanımlanmaktadır Pazarlama araştırmacıları, tüketicilerin sosyal medya reklamlarına iliş̧in tutum ve satın alma niyetlerini incelemek ve öncüllerini belirlemek için motivasyon teorisinden yararlanmışlardır. Dışsal motivasyon, algılanan yararlılığı ifade ederken; içsel motivasyon ise eylemin kendisine olan ilgiyi ifade etmektedir. Bu çalışma, motivasyon teorisinin ışığında, tüketicilerin sosyal medya reklamcılı̆̆ına yönelik tutumlarını ve satın alma niyetlerini etkileyen faktörleri incelemektedir. Bu kapsamda bu çalışmanın amacı; dışsal ve içsel motivasyonun tüketicilerin sosyal medya reklamcılığına yönelik tutumları üzerindeki etkisini; bununla birlikte, tüketicilerin tutumlarının da satın alma niyetleri üzerindeki etkisini araştırmaktır. Araştırmanın ana kütlesi Kayseri'de ikamet eden tüketicilerden oluşmaktadır. Kolayda örnekleme yöntemiyle seçilen 354 tüketici üzerinde gerçekleştirilen çalışma nicel araştırma yöntemlerinden yüz-yüze anket yöntemi uygulanarak yapılmışırı. Araştırmanın hipotezlerini test etmek amacıyla, Yapısal Eşitlik Modeli kullanılmıştır. Güvenilirlik analizi ve frekans analizi SPSS; doğrulayıc faktör analizi ve hipotez testleri ise AMOS istatistik programı aracıllğıyla analiz edilmiştir. Araştırmanın bulguları doğrultusunda, vakitlilik, yerleştirme ve kişiselleştirmenin dışsal motivasyon üzerinde; algılanan zevkin ise içsel motivasyon üzerinde etkili olduğu görülmektedir. Fakat, tüketici yenilikçiliğinin içsel motivasyon üzerinde anlamlı bir etkisinin bulunmadığı sonucuna ulaşılmıştır. Bununla birlikte dışsal ve içsel motivasyonun tutum üzerinde; tutumun ise satın alma niyeti üzerinde etkili olduğu sonucu ortaya konmuştur. Bu çalışma sonuçlarının literatürde yer alan diğer çalışma sonuçlarını desteklediği görülmüştür.

\section{Investigation of the Effect of Social Media Advertising on Consumer Buying Behavior Using Structural Equation Modeling}

\begin{abstract}
Today, advertising has become a very important promotion activity for goods and service providers. In order for an advertising campaign to be successful, an effective strategy must be put forward. The strategies developed by the company are communicated to consumers by some advertising tools. Social media advertising is defined as a series of actions that enable companies to communicate and interact with consumers in the target market via a mobile device or network in an interactive manner. Marketing researchers have used motivation theory to examine consumers' attitudes and purchase intentions towards social media ads and determine their premises. Extrinsic motivation expresses perceived usefulness; intrinsic motivation refers to the interest in the action itself. In the light
\end{abstract}

\footnotetext{
* Sorumlu Yazar: Nuh Naci Yazgan Üniversitesi, İktisadi ve İdari Bilimler Fakültesi, İşletme Bölümü, Kayseri, Türkiye, ORCID: 0000-00027504-154X, ssargin@nny.edu.tr
} 
of motivation theory, this study examines the attitudes of consumers towards social media advertising and the factors affecting their purchase intentions. In this context, the purpose of this study is to examine the effect of extrinsic and intrinsic motivation on consumers' attitudes towards social media advertising and also the effect of consumers' attitudes on purchasing intentions. The main mass of the research consists of consumers residing in Kayseri. The study, which was carried out on 354 consumers selected by convenience sampling method was conducted by applying face-to-face questionnaire method, one of the quantitative research methods. In order to test the hypotheses of the research, the Structural Equation Model was used. Reliability analysis and frequency analysis were analyzed through SPSS; confirmatory factor analysis and hypothesis tests were analyzed through the AMOS statistic programs. In line with the findings of the research, timeliness, placement, and personalization have effect on extrinsic motivation; besides, perceived pleasure seems to have an effect on intrinsic motivation. However, it is concluded that consumer innovativeness does not have a significant effect on intrinsic motivation. Moreover, extrinsic and intrinsic motivation have effect on attitude and the attitude has an effect on the purchase intention. Review of the literature supported that the study results in these application were similar to those in other results.

Keywords: Consumer Behavior, Social Media, Advertising, Motivation, Structural Equation Modeling

\section{Giriş}

Küreselleşen dünyada mal ve hizmet sağlayıcılar için reklam çok önemli bir tanıtım aracı haline gelmiştir. Reklam ifadesi geniş uygulama alanı olduğu için birbiri arasında benzerlik ve farklılık gösteren pek çok tanıma sahiptir. En basit tanımıla reklam, bir malın veya hizmetin belli bir bedel karşılığında genel yayın vasıtalarında tanıtılarak büyük hedef kitlelerine duyurulmasıdır (Ünsal, 1984, s. 12). Reklam birçok unsuru içinde barındırmasının yanında aynı zamanda ekonomik bir faaliyettir. Gündelik hayatla etkinleşmesi, satın alma tercihlerini etkilemesi ve tüketicilerin hayatını şekillendirmesi gibi unsurlardan dolayı reklam ekonomilerde önemli bir yer edinmiştir. Ekonomik yaşamda pazarlama faaliyetlerinin geniş kitle ve alanlara yayılmasını sağlayan temel eylemler, kuşkusuz öncelikle üretim, dağıtım, buna paralel olarak da satışı destekleyen çabaların varlığıdır. Reklam, bu yönüyle dağıtıma eşlik eden ve üretime katkıda bulunan bir ekonomik karakter taşımaktadır. $\mathrm{Bu}$ nedenle işletmeler için hayati öneme sahiptir (Babacan, 2005, s. 31).

Günümüz tüketim toplumunda işletmeler, onların sunduğu hizmetler/ürünler ve markalar başrolü üstlenmektedir. Bir işletmenin hizmetini veya ürününü almak aynı zamanda bir statüyü de beraberinde edinmek anlamına gelmektedir. Bu statü ediniminde kullanılacak en etkili yöntem reklamdır. Bu reklam faaliyetleri yürütülürken sürekli iletişim halinde olunması gerekmektedir. Sürekli iletişimin olması müşterinin aklında daha uzun süre kalınması anlamına gelmektedir. Müşterinin aklında kalmanın en iyi yolu ise reklam iletişiminin sağlanmasıdır (Belch ve Belch, 2004).

Tüketiciler üzerinde istenen etkiyi oluşturabilmesi için bir reklam kampanyasının doğru tasarlanmış yaratıcı bir stratejiyi ortaya koyması gereklidir (Freze, 1983, s. 36). Bu stratejiler bazı reklam araçları ile müşteriye iletilebilmektedir. Reklam verenler reklam kanalları ile doğru mesajı hedef kitlelerine ulaştırırlar. İşletmelerin, müşteriyle iletişim kurarken farklı kanallardan birini veya bir kaçını seçmesi gerekmektedir. Günümüzde birçok reklam aracı mevuttur. Farklı medya içerikleri televizyon, gazete, dergi, billboard, broşür vb. olarak sunulabilmektedir. İnsanların internette alternatif bir dünya ve bir toplum oluşturmasıyla internet ve sosyal medya reklamcılığının doğuşuna zemin hazırlanmıştır (Sinkovics, Pezderkab, \& Haghirian, 2012). Sosyal medya reklamcılı̆̆ı; işletmelerin, hedef kitleleriyle herhangi bir mobil cihaz veya ă aracilı̆̆ıla etkileşimli bir şekilde iletişim ve ilişki kurmasını sağlayan eylemler dizisi olarak tanımlanmaktadır (Johnson vd., 2013).
Sosyal medya; yapısı, katılımcıları, algılanışı ve kullanış biçimi ile pek çok avantaj içermektedir. Sosyal medya katılımcılarına neredeyse hiç bir mecranın sunmadığ özgürlükler ve olanaklar sunar. Katılımcılarının istekleri doğrultusunda gelişir ve değişir. Katılımcılar sosyal medyada iletişim konusunda da neredeyse sınırsız olanaklara sahiptir. Diğer medya organları tek yönlü iletişim içerirken, sosyal medyada insanlar düşüncelerini belirtmeye firsat bulabilmektedir. İnsanlar sosyal medyada kültürel rahatsızlar çekmemektedir çünkü sosyal medya toplumun kültüründen beslenir ve insanların kültürlerini besler. Kullanıcılar sosyal medyada farklı uçları birbirine bağlarlar ve kendilerine en uygun atmosferi yaratmayı çalışırlar. Bununla birlikte, diğer medya organlarının aksine sosyal medya dinamiktir; kolayca yorumlanıp geri bildirim verilebilir. Sosyal medya eleştiriler 1şığında kendini sürekli günceller. En büyük avantajı ise, sosyal medyanın herkes tarafından ulaşılabilir ve kullanılabilir olmasıdır. (Shankar, Venkatesh, Hofacker, \& Naik, 2010; Ghose \& Han, 2011). Sosyal medyada reklamlar Facebook, Instagram, Twitter, LinkedIn, SnapChat, Swarm gibi birçok platform ile hedef kitlelere ulaşabilmektedir. Bu gibi avantajlarından dolayı sosyal medya platformlarında reklam yapmak ve tüketicilerin tutum ve davranışlarını etkileyebilmek cazip hale gelmiştir. Literatürde reklamların tüketici motivasyon tutum ve davranışlarını inceleyen birçok çalışma mevcuttur. Şimşek (2013)'ün çalışması kullanıcıların geleneksel mecralarda gördüğü reklamları sosyal ağlarda (Facebook, Twitter, Youtube) paylaşmaları ile ilgili motivasyonlarını betimlemeyi ve hangi tür reklamların paylaşılmaya değer bulduklarını ortaya koymayı amaçlayan bir alan araştırmasıdır. Can ve Serhateri (2016)'nin çalışmasında sosyal medya reklamlarının markaya yönelik tutumlara etkisi incelenmiştir. Aktaş ve Aktan (2014), çalışmalarında Facebook'un bir reklam mecrası olarak tüketici tutumlarına nasıl etki ettiğini ve satın alma davranışı üzerindeki fonksiyonunu araştırmışlardır. KHang vd. (2012) ise, çalışmalarında reklamcılık, iletişim, pazarlama ve halkla ilişkilerde sosyal medya araştırmasını incelemişlerdir.

Pazarlama ve reklam araştırmacıları; tüketicilerin sosyal medya reklamlarına yönelik tutum ve niyetlerini ölçmek ve öncüllerini belirlemek için teknoloji kabul modeli, motivasyon teorisi, tahmin teorisi, gerekçeli eylem teorisi gibi birçok farklı teori uygulamışlardır. Motivasyon teorisi, hem dışsal hem de içsel motivasyonların insanların bilgi teknolojilerini kullanma niyetlerini etkilediği sonucuna ulaşmaktadır (Davis vd, 1992; Kim vd., 2007; Allam vd., 2019; Lu ve Su, 2009; Van der Heijden, 2004). Daha önce yapılan araştırmalar, tüketicilerin bilgi teknolojisini kabul etme davranışını açıklamak için yaygın olarak motivasyon teorisini kullanmıştır. Deci ve Ryan (1975), 
tüketici davranışının altında yatan motivasyonları dışsal motivasyon ve içsel motivasyon olarak ikiye ayırmıştır. Bunun yanında, bilgi teknolojileri söz konusu olduğunda, bireylerin elde edilen içsel ödüller (zevk ve eğlence), algılanan faydalar (yararlılık) veya dış baskılar (sosyal baskı) nedeniyle motive edilebileceğini öne sürmüşlerdir (Deci ve Ryan, 1975). Dışsal motivasyon, algılanan yararlılığı ifade ederken; içsel motivasyon eylemin kendisine olan ilgiyi ifade etmektedir (Davis ve diğerleri, 1992). Birçok araştırmacı hem dişsal (yararlılık) hem de içsel (zevk alma) faktörlerin bilgi teknolojisi sistemlerini kullanma motivasyonunu etkilediğini öne sürmüştür. Wu ve Lu (2013) davranışsal niyet çalışmaları bağlamında, zevk ve kullanışlılığın sırasıyla en belirgin ve dışsal motivasyon unsurları olduğunu ifade etmiştir (Davis vd., 1992; Lin ve Lu, 2011; Kim ve diğerleri, 2007; Lin ve Bhattacherjee, 2008; Moon ve Kim, 2001; Teo, Lim, \& Lai, 1999; van der Heijden, 2004; Lu ve $\mathrm{Su}, 2009$ ). Motivasyon teorisi uygulayarak, iç ve diş motivasyon değişkenlerini belirleyen ve sosyal medya araştırmalarını ele alan birçok çalışma mevcuttur (Koo, Chung ve Nam, 2015; Chung ve Koo,2015; Akhlaq ve Ahmed,2013). $\mathrm{Bu}$ çalışmalardan biri olan Fagan vd. (2008) çalışmaları neticesinde, içsel motivasyon ile dişsal motivasyon arasında pozitif bir ilişki olduğunu bulmuştur.

Sosyal ağ platformlarının hem iç hem de dış motivasyonların davranışsal niyeti etkilediği ve tüketiciler tarafindan algılanan faydaların motivasyon faktöründen kaynaklandığ 1 tespit edilmiştir (Kim, Chan ve Gupta, 2007). Bu iki motivasyonun tüketicinin bilgi teknolojisini kullanma niyetini etkilediği ifade edilmiştir (Kim ve ark. 2007; Lin ve Lu, 2011). Tutum, gerçek davranışın ne kadar olumlu veya olumsuz olduğuna dair düşüncelerdir (Ajzen ve Fishbein, 1980). Bu nedenle, sosyal platformları kullanmaya yönelik tutum, bu tür araçları kullanmanın iyi bir fikir olup olmadığı ve platform kullanıcılarının ne kadarının bunları kullanmayı tercih ettiği konusundaki görüşleri içerir. Tutum, geçmiş deneyimlere ve mevcut duyuşsal ve bilişsel bilgilere göre şekillenir ve insanların belirli bir eyleme yönelik davranışları üzerinde etkisi olduğu söylenir. (Fishbein and Ajzen, 1975) Ayrıca, sosyal ă̆ platformlarının kullanımı bağlamında, önceki çalışmalar, motivasyonun, kullanıcının bu platformları kullanma niyetleri üzerinde önemli bir etkiye sahip olduğunu bulmuştur (Dhir et al., 2018; Qin, Kim, \& Tan, 2016; Mouakket, 2015; Sledgianowski \& Kulviwat, 2009). Bu nedenlere dayanarak, bu çalışma da, tüketicilerin sosyal medya reklamcılığına yönelik tutum ve satın alma niyetlerine yönelik motivasyonu dişsal ve içsel olarak önermektedir.

$\mathrm{Bu}$ çalışmada, sosyal medya reklamlarının vakitliliğ (zamanlaması), yerleştirilmesi ve kişiselleştirilmesi dışsal motivasyonun öncülleri olarak; tüketici yenilikçiliği ve algılanan zevk ise içsel motivasyonun öncülleri olarak belirlenmiştir. Araştırmacılar, reklamın yerleştirildiği alanın müşterilerin tepkilerini değiştirebildiğini öne sürerek sosyal medya reklamcılığındaki önemini vurgulamışlardır (Ho, 2012; Rajala \& Westerlund, 2010). Ayrıca araştırmacılar yerleştirme ve vakitlilik açısından, tüketicilerle en uygun anda iletilen mesajların, doğru iletişimin kurulmasına imkan tanıdığını ifade etmişlerdir (Balasubramanian, Peterson ve Jarvenpaa, 2002, Hui, Inman, Huang ve Suher, 2013; Chung, Rust ve Wedel, 2009). Sosyal medya reklamcılığı, mobil cihazlar tüketicilerin kimlik bilgilerini taşıdığı için kişiselleştirme potansiyeli sağlamaktadır (Lee \& Benbasat, 2003). Pazarlamacılar, müşterilerin tercihleri hakkında bilgi toplayabilirler. Bununda ötesinde; geri bildirimlerini, şirketin gelecekteki ürün ve hizmetlerini iyileştirmek için, mesajlarını ve tekliflerini özelleştirmek için kullanabilirler (Stewart \& Pavlou, 2002). Bu dişsal faktörlere ek olarak, tüketici yenilikçiliği (tüketicilerin yeni ürünlere, hizmetlere veya uygulamalara ne ölçüde açık oldukları) ve algılanan zevk (bir ürünü kullanma faaliyetinin ne ölçüde algılandığı) olmak üzere iki içsel motivasyon faktörü belirlenmiştir. Yenilik aramak, yenilikçi tüketicilerin doğasının bir parçasıdır (Allam vd, 2019; Ryan, Deci, Nix ve Manly, 1999). Önceki çalışmalar, tüketici yenilikçiliğinin, yeni teknolojilerin benimsenmesinin esas itici gücü olduğunu göstermektedir (Reis, 1994). Ayrıca reklamların kısa, öz ve eğlenceli olması alıcılar arasında keyif yaratması açısından önemlidir (Xu, 2006). Zevk, bir duygudur ve tüketicilerin reklamı yapılan ürüne ilgisini uyandırabilir (Altuna ve Konuk, 2009). Bu nedenle zevk, tüketicileri dışsal olarak baskılar veya ödüllerden ziyade eğlence amaçlı tavsiyeleri, ürün ve hizmetleri kabul etmeye motive eder (Reeve, 1989).

Özet olarak, bu çalışmanın temel araştırma sorusu şudur: Tüketicilerin sosyal medya reklamcılığını kabul etme motivasyonunu hangi faktörler artırmaktadır? İçsel ve dışsal motivasyonlarla ilgili faktörleri araştırarak bunların tüketicilerin sosyal medya reklamcılığına yönelik tutumları ve satın alma niyetleri üzerindeki etkileri nasıldır? Bu makalede giriş bölümü çalışma teorisini ve literatür araştırmasını içermektedir. Bir sonraki bölümde ise; mevcut çalışmanın amacı, önemi ve yöntemi, araştırma modeli ve hipotezleri açıklanmaktadır. Üçüncü bölüm, verilerin analizi ve sonuçlarını içermektedir. Dördüncü bölümde ise, bu araştırmanın çıkarımları ve sınırlamaları ile gelecek çalışmalar için olası öneriler özetlenmektedir.

\section{Materyal ve Metot}

\subsection{Araştırmanın Amacı ve Önemi}

Günümüzde mobil cihazların her geçen gün biraz daha popüler hale gelmesi nedeniyle sosyal medya reklamcılığı da buna paralel olarak hızla yaygınlaşmaktadır. $\mathrm{Bu}$ çalışma, motivasyon teorisinden yararlanarak, tüketicilerin sosyal medya reklamcılığına yönelik tutumlarını ve satın alma niyetlerini etkileyen faktörleri incelemektedir. Reklam mesajının vakitliliği, yerleştirilmesi ve kişiselleştirilmesi dişsal motivasyonun öncülleri olarak; tüketici yenilikçiliği ve algılanan zevk ise içsel motivasyonun öncülleri olarak tanımlanmaktadır. Bu doğrultuda bu çalışmanın amacı; dışsal ve içsel motivasyonun tüketicilerin sosyal medya reklamcılığına yönelik tutumları üzerindeki etkisini, bununla birlikte, tüketicilerin tutumlarının da satın alma niyetleri üzerindeki etkisini araştırmaktır.

\subsection{Araştırmanın Modeli ve Hipotezler}

Araştırmanın amacı doğrultusunda araştırmanın modeli Şekil.1'deki gibi oluşturulmuştur. Önerilen model, motivasyon modelinin teorik bir kombinasyonu olarak geliştirilmiştir (Feng, Fu ve Qin, 2016; Lin ve Lu, 2011). 


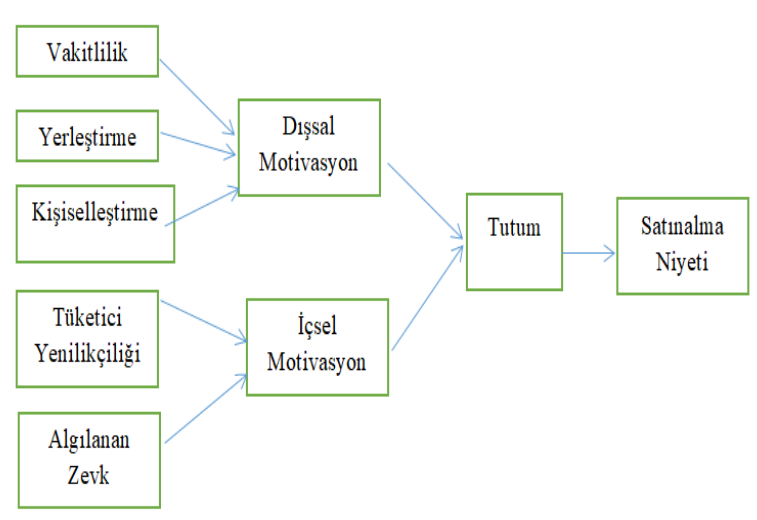

Şekil.1 Araştırmanın Modeli

Araştırmanın modeli kapsamında hipotezler aşağıda belirtildiği şekilde oluşturulmuştur:

H1: Vakitliliğin dişsal motivasyon üzerinde anlamlı bir etkisi vardır.

$\mathrm{H} 2$ : Yerleştirmenin dışsal motivasyon üzerinde anlamlı bir etkisi vardır.

H3: Kişiselleştirmenin dişsal motivasyon üzerinde anlamlı bir etkisi vardir.

H4: Tüketici yenilikçiliğinin içsel motivasyon üzerinde anlamlı bir etkisi vardır.

H5: Algılanan zevkin içsel motivasyon üzerinde anlamlı bir etkisi vardır.

H6: Dışsal motivasyonun tutum üzerinde anlamlı bir etkisi vardır.

H7: İçsel motivasyonun tutum üzerinde anlamlı bir etkisi vardir.

H8: Tutumun satın alma niyeti üzerinde anlamlı bir etkisi vardir.

\subsection{Araştırmanın Yöntemi}

Araştırmanın ana kütlesi Kayseri'de ikamet eden tüketicilerden oluşmaktadır. Örneklem yöntemi olarak kolayda örnekleme yönetimi kullanılmıştır. Kolayda örnekleme yöntemi ile veriler, ana kütleden kolay, hızlı ve ekonomik bir biçimde elde edilebilmektedir (Zikmund, 1997, s. 428). 30 tüketiciye uygulanan pilot çalışma sonrasında, Mart-Haziran 2019 tarihleri aralığında 354 tüketici üzerinde gerçekleştirilen çalışma nicel araştırma yöntemlerinden yüzyüze anket yöntemi uygulanarak yapılmıştır. Anket yöntemi kısa zamanda birçok cevaplayıcıya ulaşılabilmesi ve düşük maliyetli bir veri toplama yöntemi olması nedeniyle çoğunlukla tercih edilmektedir (Yazıcıoğlu ve Erdoğan, 2004, s. 51).

Uygulanan anket formu 2 bölümden meydana gelmektedir. Birinci bölümde vakitlilikle ilgili 4, Yerleştirmeyle ilgili 3, kişiselleştirmeyle ilgili 3, tüketici yenilikçiliğiyle ilgili 3, algılanan zevkle ilgili 4 ifade yer almaktadır. Dışsal motivasyona ilişkin 4, içsel motivasyona ilişkin ise 3 ifadenin yer aldığı bu bölümde, tutumu ölçen 4 adet ifade ve satın alma niyetiyle ilgili de 3 ifade bulunmaktadır. Toplam 31 ifadenin yer aldığ 1 bu bölümde kullanılan vakitlilik, kişiselleştirme ve yerleştirme ifadeleri Pihlstrom ve Brush (2008); Ducoffe (1996), Merisavo vd. (2007) ve Feng vd. (2016); tüketici yenilikçiliği ifadeleri
Feng vd. (2016), Goldsmith ve Hofacker (1991) Citrin vd. (2000); algılanan zevk ifadeleri Feng vd. (2016), Ducoffe (1996); içsel ve dışsal motivasyon ifadeleri Vallerand vd. (1992), Pelletier vd.(1995), Feng vd. (2016); tutum ifadeleri Feng vd. (2016); satın alma niyeti ifadeleri ise Putrevu ve Lord (1994) tarafından geliştirilen ölçeklerden uyarlanarak hazırlanmıştır. Anket formunun ikinci bölümünde ise; katılımcıların demografik özelliklerini belirlemeye yönelik 9 adet ifade yer almaktadır.

Anket formunda yer alan ifadeler cevaplayıcıların kolayca anlayabileceği şekilde düzenlenmiştir. Ölçeklerde yer alan ifadeler, "kesinlikle katılmıyorum" (1) ile "kesinlikle katılıyorum "(5) arasında puanlamanın yapıldığg 5 'li likert ölçeği kullanılarak hazırlanmıştır.

\section{Araştırma Sonuçları ve Tartışma}

Araştırma verilerinin analiz edilmesi aşamasında öncelikle cevaplayıcıların demografik özelliklerini belirlemeye yönelik frekanslar incelenmiştir. Ardından araştırmada yer alan ölçeklerin güvenilirlik analizleri yapılmıştır. Ölçeklerin boyutları arasında yeterli düzeyde bir ilişki var olup olmadığını ve bu boyutların modeli yeterince ifade edip edemediğini incelemek maksatlı doğrulayıcı faktör analizi gerçekleştirilmiştir. Araştırmanın hipotezlerini test etmek amacıyla ise, yapısal eşitlik modeli kullanılmıştır. Güvenilirlik analizi ve frekans analizi SPSS, doğrulayıcı faktör analizi ve hipotez testleri ise AMOS istatistik programı aracılığıyla analiz edilmiştir. Araştırmada yapılan analizler ve elde edilen bulgular aşağıda yer alan ilgili tablolarda verilmiş ve yorumlanmıştır.

Uygulanan anketlerden elde edilen veriler sonucunda Tablo.1'de görüldüğü üzere, katılımcıların \%47,7'sinin 25-35 yaş aralığında, \%44,9'unun üniversite mezunu, \%52,8'inin kadın, \%47,2'sinin erkek, \%52,5'unun bekar olduğu; \%36,7'sinin gelirinin ise 2021-3500 TL aralığında bulunduğu sonucuna ulaşılmaktadır.

Tablo. 1 Katılımcılardan Elde Edilen Demografik Bilgiler

\begin{tabular}{|c|c|c|c|c|c|c|c|}
\hline \multicolumn{2}{|c|}{ Demografik Özellikler } & \multirow{2}{*}{$\begin{array}{l}\mathbf{n} \\
31\end{array}$} & \multirow{2}{*}{$\begin{array}{l}\% \\
8,8\end{array}$} & \multicolumn{2}{|c|}{ Demografik Özellikler } & \multirow{2}{*}{$\begin{array}{l}\mathbf{n} \\
187\end{array}$} & \multirow{2}{*}{$\begin{array}{l}\% \\
52,8\end{array}$} \\
\hline Yaş & $14-18$ & & & Cinsiyet & Kadın & & \\
\hline & $18-24$ & 85 & 24 & & Erkek & 167 & 47,2 \\
\hline & $25-35$ & 169 & 47,7 & & Toplam & 354 & 100 \\
\hline & $36-45$ & 43 & 12,1 & Medeni & Evli & 168 & 47,5 \\
\hline & $46-55$ & 14 & 4 & Durum & Bekar & 186 & 52,5 \\
\hline & 55 üzeri & 12 & 3,4 & & Toplam & 354 & 100 \\
\hline & Toplam & 354 & 100 & Gelir & $0-1000 \mathrm{TL}$ & 36 & 10,2 \\
\hline \multirow{11}{*}{$\begin{array}{l}\text { Öğrenim } \\
\text { Durumu }\end{array}$} & İlköğretim & 46 & 13 & & $1001-2020$ & 115 & 32,5 \\
\hline & & & & & $T L$ & & \\
\hline & Lise ve & 131 & 37 & & 2021-3500 & 130 & 36,7 \\
\hline & Dengi & & & & $T L$ & & \\
\hline & Üniversite & 159 & 44,9 & & $3501-5500$ & 59 & 16,7 \\
\hline & & & & & $T L$ & & \\
\hline & Lisansüstü & 18 & 5,1 & & $5501-8500$ & 11 & 3,1 \\
\hline & & & & & $T L$ & & \\
\hline & Toplam & 354 & 100 & & 8500 & 3 & 0,8 \\
\hline & & & & & $\ddot{u z e r i}$ & & \\
\hline & & & & & & 354 & 100 \\
\hline
\end{tabular}




\subsection{Güvenilirlik Analizi}

Araştırmada kullanılan ölçeklere yapılan güvenilirlik analizi sonucunda elde edilen Cronbach Alpha Katsayıları Tablo.2'de gösterilmektedir. Güvenilirlik analizi sonucu elde edilen cronbach alpha katsayıları değerlendirildiğinde, anket formunda bulunan ifadelerin yüksek düzeyde güvenilir olduğu sonucu ortaya çıkmaktadır. Ölçeklerin güvenilir olduğunu tespit edebilmek için alpha değerinin 0,70 ve yukarısında olması gerekmektedir (Nunnally, 1978).

Tablo.2 Araştırmada Kullanılan Ölçeklerin Güvenilirlikleri

\begin{tabular}{lc}
\hline Ölçekler & Cronbach Alpha Katsayıları \\
\hline Satın Alma Niyeti Ölçeği &, 943 \\
Algılanan Zevk Ölçeği &, 936 \\
Vakitlilik Ölçeği &, 933 \\
Dısssal Motivasyon Ölçeği &, 927 \\
İçsel Motivasyon Ölçeği &, 915 \\
Yerleştirme Ölçeği &, 895 \\
Tüketici Yenilikçiliği Ölçeği &, 895 \\
Kişiselleştirme Ölçeği &, 886 \\
Tutum Öllçeği &, 797 \\
\hline
\end{tabular}

\subsection{Doğrulayıcı Faktör Analizi}

Doğrulayıcı faktör analizi, ölçeklere ait faktörler arasında yeterli düzeyde bir ilişki bulunup bulunmadığını ve faktörlerin modeli açıklamak açısından yeterli olup olmadığını test etmek amacıyla yapılmaktadır (Bayram, 2010). Bu şekilde, faktör yapıları ve yükleri değerlendirilmekte ve anket formunda yer alan ölçeklerin geçerli olup olmadıkları test edilmektedir. Analiz edilen model Şekil.2'de yer almaktadır.

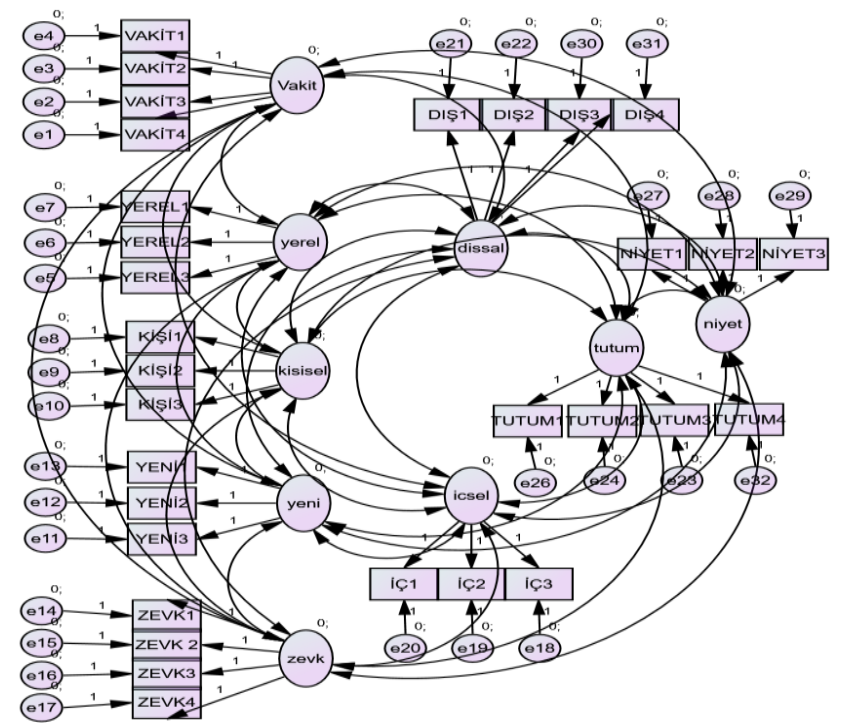

Şekil.2 Doğrulayıcı Faktör Analizi Modeli

Ölçüm sonucu ulaşılan uyum iyiliği değerleri, araştırma modeli ve kabul edilebilir değerler Tablo.3'de verilmiştir. Uyum iyiliği değerlerinin kabul edilebilir sınırlarını elde etmek için Bentler ve Bonett, 1980'in çalışmalarından faydalanılmıştır.

\begin{tabular}{|c|c|c|c|}
\hline Uyum İndeksleri & $\begin{array}{l}\text { Araştırma } \\
\text { Modeli } \\
(\mathrm{N}=354)\end{array}$ & $\begin{array}{l}\text { Kabul Edilen } \\
\text { Değerler }\end{array}$ & Kisaltmalar \\
\hline$X^{2}$ Değeri & 1436,786 & 000 & CMIN \\
\hline Serbestlik Derecesi & 418 & 0 & $\mathrm{DF}$ \\
\hline$P$ &, 000 & $<, 005$ & $\mathrm{P}$ \\
\hline$X^{2} / d f$ & 3,437 & $<5$ & CMIN/DF \\
\hline $\begin{array}{l}\text { Normlaştırlmış Uyum İyiliği } \\
\text { İndeksi }\end{array}$ & 900 &, $90 \leq \mathrm{NFI} \leq, 95$ & NFI \\
\hline Artırmalı Uyum Indeksi & ,923 &, $90 \leq \mathrm{IFI} \leq, 95$ & IFI \\
\hline Karşılaşstırmalı Uyum İndeksi & ,923 &, $90 \leq \mathrm{CFI} \leq, 95$ & CFI \\
\hline $\begin{array}{l}\text { Yaklaşık Hataların Ortalama } \\
\text { Karekökü }\end{array}$ & 083 &, $05 \leq$ RMSEA $\leq, 08$ & RMSEA \\
\hline
\end{tabular}

Veriler ile model arasında uyum bulunup bulunmadığını inceleyen istatistiklerden en çok kullanılanlardan biri ki-kare istatistiğidir (Bayram, 2010). Ölçüm sonuçları incelendiğinde kikare istatistiğinin anlamlı olduğu sonucuna ulaşılmaktadır $(\mathrm{p}=0,000)$. Standart ki-kare değeri ise ki-kare değerinin serbestlik derecesine oranını ifade etmektedir. Standart ki-kare değerinin 3,437 olduğu görülmektedir. Bu değerin 5'in altında bir değer almas1, kabul edilebilir bir değer olduğunu göstermektedir (Chen ve Tsai, 2007). Tablo.4 'de yer alan uyum iyiliği değerleri ve kabul edilebilir değerlere bakıldığında, verinin modelle uyumlu bir veri olduğu sonucuna ulaşılmaktadır. Doğrulayıcı faktör analizi sonucu modelde yer alan değişkenlerin regresyon katsayıları Tablo.4'de yer almaktadır.

Tablo. 4 Modelde Yer Alan Değişkenlerle Illgili Faktör Yükleri

\begin{tabular}{|c|c|c|c|}
\hline Değişkenler & Faktör Yükleri & Değişkenler & Faktör Yükleri \\
\hline Satın Alma 3 & ,927 & $\dot{I}$ çsel Motivasyon 3 &, 880 \\
\hline Satın Alma 2 & ,919 & Algilanan Zevk 1 & ,879 \\
\hline Satın Alma 1 & ,907 & $\begin{array}{l}\text { Dişsal } \\
\text { Motivasyon } 2\end{array}$ & ,877 \\
\hline Algllanan Zevk 3 & ,903 & $\begin{array}{l}\text { Tüketici } \\
\text { Yenilikçiliği } 3\end{array}$ &, 874 \\
\hline Vakitlilik 2 & ,893 & Vakitlilik 1 & ,867 \\
\hline Tüketici Yenilikçiliği 2 & ,889 & Kişiselleştirme 2 & ,865 \\
\hline İçsel Motivasyon 2 & ,888 & $\begin{array}{l}\text { Dışsal } \\
\text { Motivasyon } 1\end{array}$ & ,865 \\
\hline Içsel Motivasyon 1 & ,888 & Tutum 1 & ,864 \\
\hline Tutum 3 & ,888 & Yerleştirme 3 & ,862 \\
\hline Dışsal Motivasyon 3 & ,888 & Yerleştirme 1 & ,862 \\
\hline Tutum 4 & ,886 & $\begin{array}{l}\text { Dışsal } \\
\text { Motivasyon } 4\end{array}$ & ,859 \\
\hline Algllanan Zevk 2 & ,885 & Yerleştirme 2 & ,858 \\
\hline Tüketici Yenilikçiliği 1 & ,884 & Kişiselleştirme 1 &, 852 \\
\hline Algllanan Zevk 4 & ,884 & Kişiselleş̧tirme 3 &, 833 \\
\hline Vakitlilik 4 & ,883 & Tutum 2 &, 519 \\
\hline Vakitlilik 3 &, 882 & & \\
\hline
\end{tabular}

Tablo.3 Model ile Veriler Arasındaki Uyumun İncelenmesi 


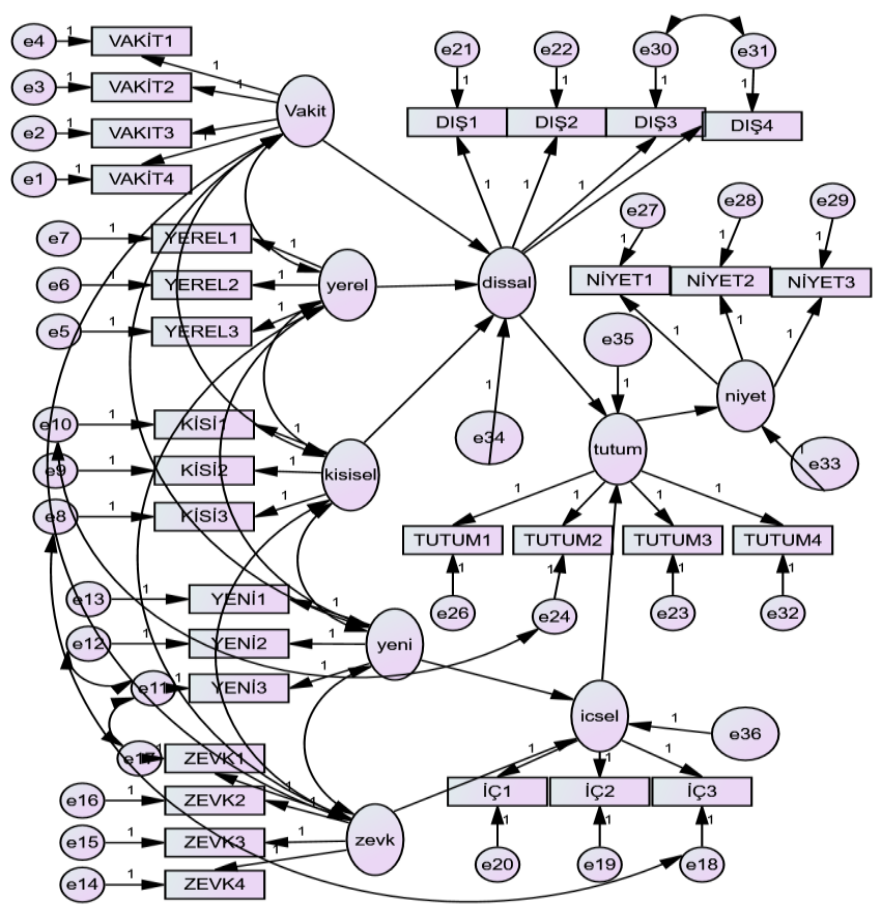

Şekil.3 Yapısal Eşitlik Modeli

Şekil.3'de yer alan yapısal eşitlik modelinin test edilmesi neticesinde elde edilen uyum iyiliği değerleri ve kabul edilebilir değerler Tablo.5'de yer almaktadır.

Tablo.5 Yapısal Eşitlik Modelinin Test Edilmesi Sonucu Elde Edilen Uyum Değerleri

\begin{tabular}{|c|c|c|c|}
\hline Uyum İndeksleri & $\begin{array}{l}\text { Araştırma } \\
\text { Modeli }\end{array}$ & $\begin{array}{c}\text { Kabul } \\
\text { Edilen Değerler }\end{array}$ & Kisaltmalar \\
\hline$X^{2}$ Değeri & 1485,022 &, 000 & CMIN \\
\hline Serbestlik Derecesi & 429 & 0 & DF \\
\hline$P$ &, 000 & $<, 005$ & $\mathrm{P}$ \\
\hline$X^{2} / d f$ & 3,462 & $<5$ & CMIN/DF \\
\hline Uyum İyiliği İndeksi &, 889 &, $90 \leq \mathrm{GFI} \leq, 95$ & GFI \\
\hline $\begin{array}{l}\text { Düzeltilmiş } \quad \text { Uyum } \\
\text { Iyiliği İndeksi }\end{array}$ & ,856 &, $85 \leq \mathrm{AGFI} \leq 90$ & AGFI \\
\hline $\begin{array}{l}\text { Normlaştırılmış } \\
\text { Uyum İyiliği İndeksi }\end{array}$ & ,897 &, $90 \leq \mathrm{NFI} \leq, 95$ & NFI \\
\hline $\begin{array}{l}\text { Artırmall Uyum } \\
\text { Indeksi }\end{array}$ & ,925 &, $90 \leq \mathrm{IFI} \leq, 95$ & IFI \\
\hline $\begin{array}{l}\text { Karşılaştırmalı Uyum } \\
\text { Indeksi }\end{array}$ & ,924 &, $90 \leq \mathrm{CFI} \leq, 95$ & CFI \\
\hline $\begin{array}{l}\text { Yaklaşık Hataların } \\
\text { Ortalama Karekökü }\end{array}$ &, 084 &, $05 \leq$ RMSEA $\leq, 08$ & RMSEA \\
\hline
\end{tabular}

Modelin uyum iyiliği değerleri incelendiğinde, bütün değerlerin kabul edilebilir sınırlar içerisinde yer aldığı ve modelin geçerli bir model olduğu sonucuna ulaşılmaktadır. Uyum değerlerinin incelenmesinin ardından, yapısal eşitlik modelinde yer alan regresyon katsayılarının da değerlendirilmesi gerekmektedir.
Tablo.6 Değişkenler Arasında Oluşturulan Yapısal Eşitlik Modeli Regresyon Katsayıları

\begin{tabular}{|c|c|c|c|c|}
\hline Hipotez & Değişkenler & $\begin{array}{c}\text { Tahmi } \\
\text { n }\end{array}$ & $\begin{array}{c}\text { Standart } \\
\text { Hata }\end{array}$ & $\mathbf{P}$ \\
\hline$H 1$ & $\begin{array}{l}\text { Vakitlilik } \longrightarrow \\
\text { Dışsal Motivasyon }\end{array}$ & 1,277 & ,371 & ,000 \\
\hline$H 2$ & $\begin{array}{l}\text { Yerleştirme } \longrightarrow \\
\text { Dişsal Motivasyon }\end{array}$ & 1,739 & ,592 & ,003 \\
\hline$H 3$ & $\begin{array}{l}\text { Kişiselleştirme } \longrightarrow \\
\text { Dışsal Motivasyon }\end{array}$ & 1,500 & 287 & ,000 \\
\hline$H 4$ & $\begin{array}{l}\text { Tüketici Yenilikçiliği } \\
\text { İçsel Motivasyon }\end{array}$ & ,124 & , 106 & ,244 \\
\hline H5 & $\begin{array}{l}\text { Algılanan Zevk } \\
\text { İçsel Motivasyon }\end{array}$ & 1,114 & , 104 & ,000 \\
\hline H6 & $\begin{array}{l}\text { Dişsal Motivasyon } \\
\text { Tutum }\end{array}$ &, 562 & ,068 & ,000 \\
\hline$H 7$ & $\begin{array}{l}\text { İcsel Motivasyon } \\
\text { Tutum }\end{array}$ & ,415 & 067 & ,000 \\
\hline$H 8$ & $\begin{array}{l}\text { Tutum } \longrightarrow \\
\text { Satin Alma Niyeti }\end{array}$ & 1,034 & 0,030 & ,000 \\
\hline
\end{tabular}

Tablo.6'da bulunan dişsal motivasyonu etkileyen değişkenler incelendiğinde, vakitliliğin, yerleştirmenin ve kişiselleştirmenin dişsal motivasyon üzerinde anlamlı bir etkisi olduğu görülmektedir $(\mathrm{p}<0,05)$. Bu kapsamda, H1, H2 ve H3 olarak oluşturulan hipotezler kabul edilmiştir. İçsel motivasyon kaynakları incelendiğinde ise tüketici yenilikçiliğinin içsel motivasyon üzerinde anlamlı bir etkisi olmadığını tespit edilmiştir ( $p>0,05)$. Bu kapsamda, $\mathrm{H} 4$ hipotezi reddedilmiştir. Algılanan zevkin değişkeninin ise içsel motivasyon üzerinde anlamlı bir etkisi olduğu görülmektedir $(\mathrm{p}<0,05)$. Bu kapsamda, H5 hipotezi kabul edilmiştir.

Dişsal motivasyonun ve içsel motivasyonun tutum üzerinde anlamlı bir etkisi olduğu da görülmektedir $(p<0,05)$. Bu sebeple H6 ve H7 hipotezleri kabul edilmiştir. Tutum faktörünün satın alma niyeti üzerinde anlamlı bir etkisinin de bulunduğu da gözlemlenmiştir $(p<0,05)$. Sonuç olarak H8 hipotezi de kabul edilmiştir.

\section{Sonuç}

Mobil teknoloji günümüz dünyasında çok önemli bir yer edinmiş durumdadır. Bu sebeple hem işletmeler, hem tüketiciler tarafınfan reklamcılık kanallarından biri olması kaçınılmaz hale gelmiştir. Geniş kitlelere zaman ve maliyet açısından faydalar sağlayan bu teknoloji ile reklamlar tüketicilerle buluşmaya her geçen gün biraz daha artarak devam edecektir. Bu çalışma, motivasyon teorisinden yararlanarak, tüketicilerin sosyal medya reklamcılığına yönelik tutumlarını ve satın alma niyetlerini etkileyen faktörleri incelemektedir. Motivasyon teorisinde yer alan içsel ve dışsal motivasyon kaynaklarını oluşturan literatürde belirlenen öncüllerin etkisi ve tüketici tutumları, sosyal medya reklamcılığı üzerinden incelenmeye çalışılmıştır. Bu amaçla yapılan analizlere göre belirlenen hipotezlerin özet sonuçları Tablo.7'de sunulmuştur. 


\section{Tablo. 7 Hipotez Sonuçları}

H1: Vakitliliğin dışsal motivasyon üzerinde anlamlı bir etkisi vardır.

$\mathrm{H} 2$ : Yerleştirmenin dışsal motivasyon üzerinde anlamlı bir etkisi vardır

H3: Kişiselleştirmenin dışsal motivasyon üzerinde anlamlı bir etkisi

Kabul

Kabul

vardir

H4: Tüketici yenilikçiliğinin içsel motivasyon üzerinde anlamlı bir

Red

etkisi vardır

H5: Algılanan zevkin içsel motivasyon üzerinde anlamlı bir etkisi

vardir

H6: Dışsal motivasyonun tutum üzerinde anlamlı bir etkisi vardır

Kabul

H7: İçsel motivasyonun tutum üzerinde anlamlı bir etkisi vardır

Kabul

H8: Tutumun satın alma niyeti üzerinde anlamlı bir etkisi vardır

Kabul

Kabul

Tablo.7'de kabul ve red edilen hipotezler bulunmaktadır. Araştırmanın bulguları doğrultusunda, vakitlilik, yerleştirme ve kişiselleştirmenin dışsal motivasyon üzerinde; algılanan zevkin ise içsel motivasyon üzerinde etkili olduğu görülmektedir. Geçmiş çalışmalarda yerleştirmenin, vakitlilik ve kişiselleştirmenin müşterilerin tepkilerini değiştirebildiğini öne sürerek sosyal medya reklamcılığındaki önemini vurgulanmıştır (Ho, 2012; (Balasubramanian, Peterson ve Jarvenpaa, 2002, Chung, Rust ve Wedel, 2009; Hui, Inman, Huang ve Suher, 2013; Rajala \& Westerlund, 2010). Bu açıdan da hipotezler literatürle desteklenmektedir. Fakat, tüketici yenilikçiliğinin içsel motivasyon üzerinde anlamlı bir etkisinin bulunmadığ sonucuna ulaşılmıştır. Önceki çalışmalarda bu çalışmadan farklı sonuçlara ulaşılmış olup, tüketici yenilikçiliğinin içsel motivasyon üzerinde etkisinin olduğu ifade edilmektedir (Reis, 1994, Feng, Fu \& Qin, 2016). Bu çalışmada tüketici yenilikçiliğinin içsel motivasyon üzerinde anlamlı bir etkisinin bulunmamasının nedeninin kolayda örnekleme yönteminin bir dezavantajı olarak ortaya çıkmış olabileceği düşünülmektedir. Gelecek çalışmalarda tesadüfi örnekleme yöntemlerinden biri veya farklı örneklem büyüklükleri kullanılarak farklı sonuçlar elde edilebileceği öngörülmektedir. Algılanan zevkin ise içsel motivasyon üzerinde anlamlı bir etkisi olduğu görülmektedir ve hipotez kabul edilmiştir $(\mathrm{p}<0,05)$. Literatürde de reklamların kısa, öz ve eğlenceli olmasının alıcılar arasında keyif yaratması açısından önemli olduğu üzerinde duran çalışmalar mevcuttur (Xu, 2006; Altuna ve Konuk, 2009; Reeve, 1989). Bununla birlikte dişsal ve içsel motivasyonun tutum üzerinde; tutumun ise satın alma niyeti üzerinde etkili olduğu sonucu ortaya konmuştur. Önceki çalışmalar da bulguyu destekler niteliktedir (Dhir et al., 2018; Mouakket, 2015; Qin, Kim, \& Tan, 2016; Sledgianowski \& Kulviwat, 2009).

Bu çalışmada bazı sınırlılıklar mevcuttur. İlk olarak, ankete katılanlar çoğunlukla Kayseri ilinde yaşayan kişilerdir. Aktif olarak cep telefonu kullanan bireyler olsalar bile daha farklı bölgelerden, ülkelerden katılımcıların dahil edilmesi araştırmayı daha güçlü kılacaktır. Ayrıca bu çalışmaya reklamların özellikleri, türleri, formatları, reklam sağlayıcılar ve markalar gibi birçok farklı değişken de eklenerek araştırma genişletilebilecektir. Farklı analizlerle araştırma desteklenerek sonuçların irdelenmesi ve bakış açılarının değiştirilebilmesi mümkündür. $\mathrm{Bu}$ sayede tüketicilerin motivasyon faktörleri, tutumları ve niyetlerine yönelik davranışlarının daha kapsamlı bir şekilde anlaşılabilmesine imkan sağlanmış olacaktır.

\section{Kaynakça}

Ajzen, I., Fishbein, M., \& Heilbroner, R. L. (1980). Understanding attitudes and predicting social behavior (Vol. 278). Englewood Cliffs, NJ: Prentice-hall.

Akhlaq, A., \& Ahmed, E. (2013). The effect of motivation on trust in the acceptance of internet banking in a low income country. International journal of bank marketing.

Aktaş, H., \& Aktan, E. (2014). Sosyal medya reklamları ve tüketici tutumlarl: Bir reklam mecrası olarak Facebook. Dijital İletişim Etkisi Uluslararası Akademik Konferans Bildiri Kitabı, İskenderiye Kitap, İstanbul, 422-434.

Allam, H., Bliemel, M., Spiteri, L., Blustein, J., \& Ali-Hassan, H. (2019). Applying a multi-dimensional hedonic concept of intrinsic motivation on social tagging tools: A theoretical model and empirical validation. International Journal of Information Management, 45, 211-222.

Altuna, O. K., \& Konuk, F. A. (2009). Understandıng Consumer Attitudes Toward Mobile Advertising And Its Impact On Consumers Behavioral Intentions: A Crossmarket Comparison Of United States And Turkısh Consumers. International Journal of Mobile Marketing, 4(2).

Babacan, M. (2005). Reklamcllk temel kavramlar. Ankara: Detay Yayıncilik.

Balasubraman, S., Peterson, R. A., \& Jarvenpaa, S. L. (2002). Exploring the implications of $\mathrm{m}$-commerce for markets and marketing. Journal of the academy of Marketing Science, 30(4), 348-361.

Bayram, N. (2010). Yapısal eşittlik modellemesine giriş AMOS uygulamalart. Ezgi Kitabevi.

Belch, G. E., \& Belch, M. A. (2004). Advertising and promotion: An integrated marketing communications perspectives (8th. Ed.).New York: McGraw-Hil

Bentler, P. M., \& Bonett, D. G. (1980). Significance tests and goodness of fit in the analysis of covariance structures. Psychological bulletin, 88(3), 588 .

Can, L., \& Serhateri, A. (2016). Sosyal medya reklamlarının markaya yönelik tutuma etkisi: facebook üzerinde bir uygulama. Balkan ve Yakın Doğu Sosyal Bilimler Dergisi, 2(3), 16-28.

Chen, C. F., \& Tsai, D. (2007). How destination image and evaluative factors affect behavioral intentions?. Tourism management, 28(4), $1115-1122$

Chung, N., \& Koo, C. (2015). The use of social media in travel information search. Telematics and Informatics, 32, 215-229.

Chung, T. S., Rust, R. T., \& Wedel, M. (2009). My mobile music: An adaptive personalization system for digital audio players. Marketing Science, 28(1), 52-68.

Citrin, A. V., Sprott, D. E., Silverman, S. N., \& Stem, D. E. (2000). Adoption of Internet shopping: the role of consumer innovativeness. Industrial management \& data systems.

Davis, F. D., Bagozzi, R. P., \& Warshaw, P. R. (1989). User acceptance of computer technology: a comparison of two theoretical models. Management Science, 35(8), 982e1003.

Deci, E. L., \& Ryan, R. M. (1985). Intrinsic motivation and selfdetermination in human behavior, Springer Science \& Business Media

Deci, E. L., \& Ryan, R. M. (1995). Human autonomy. In Efficacy, agency, and self-esteem (pp. 31-49). Springer, Boston, MA.

Dhir, A., Kaur, P., \& Rajala, R. (2018). Why do young people tag photos on social networking sites? Explaining user intentions. International Journal of Information Management, 38(1), 117-127. https://doi.org/10.1016/j.ijinfomgt.2017.07.004.

Ducoffe, R. H. (1996). Advertising value and advertising on the webBlog@ management. Journal of advertising research, 36(5), 21-32.

Fagan, M. H., Neill, S., \& Wooldridge, B. R. (2008). Exploring the intention to use computers: An empirical investigation of the role of intrinsic motivation, extrinsic motivation, and perceived ease of use. Journal of Computer Information Systems, 48(3), 31-37.

Feng, X., Fu, S., \& Qin, J. (2016). Determinants of consumers' attitudes toward mobile advertising: The mediating roles of intrinsic and extrinsic motivations. Computers in Human Behavior, 63, 334-341. 
Fishbein, M., \& Ajzen, I. (1977). Belief, attitude, intention, and behavior: An introduction to theory and research.

Ghose, A., \& Han, S. P. (2011). An empirical analysis of user content generation and usage behavior on the mobile Internet. Management Science, 57(9), 1671-1691.

Goldsmith, R. E., \& Hofacker, C. F. (1991). Measuring consumer innovativeness. Journal of the academy of marketing science, 19(3), 209-221.

Ho, S. Y. (2012). The effects of location personalization on individuals' intention to use mobile services. Decision Support Systems, 53(4), 802-812.

Hui, S. K., Inman, J. J., Huang, Y., \& Suher, J. (2013). The effect of instore travel distance on unplanned spending: Applications to mobile promotion strategies. Journal of Marketing, 77(2), 1-16.

Johnson P., Plummer J., Bregman M., Clark B., Clarck D. (2013). Mobile Marketing Economic Impact Study, Mobile Marketting Associations. USA.

Khang, H., Ki, E. J., \& Ye, L. (2012). Social media research in advertising, communication, marketing, and public relations, 1997-2010. Journalism \& Mass Communication Quarterly, 89(2), 279-298.

Kim, H. W., Chan, H. C., \& Gupta, S. (2007). Value-based adoption of mobile internet: an empirical investigation. Decision support systems, 43(1), 111-126.

Koo, C., Chung, N., \& Nam, K. (2015). Assessing the impact of intrinsic and extrinsic motivators on smart green IT device use: Reference group perspectives. International Journal of Information Management, 35(1), 64-79.

Lee, Y. E., \& Benbasat, I. (2003). Interface design for mobile commerce. Communications of the ACM, 46(12), 48-52.

Lin, C. P., \& Bhattacherjee, A. (2008). Elucidating individual intention to use interactive information technologies: The role of network externalities. International Journal of Electronic Commerce, 13, 85-108.

Lin, K. Y., \& Lu, H. P. (2011). Why people use social networking sites: An empirical study integrating network externalities and motivation theory. Computers in human behavior, 27(3), 11521161.

Lu, H. P., \& Su, Y. J. P. (2009). Factors affecting purchase intention on mobile shopping web sites. Internet Research, 19, 442-458.

Merisavo, M., Kajalo, S., Karjaluoto, H., Virtanen, V., Salmenkivi, S., Raulas, M., \& Leppäniemi, M. (2007). An empirical study of the drivers of consumer acceptance of mobile advertising. Journal of interactive advertising, 7(2), 41-50.

Moon, J. W., \& Kim, Y. G. (2001). Extending the TAM for a WorldWide-Web context. Information \& Management, 38, 217-230.

Mouakket, S. (2015). Factors influencing continuance intention to use social network sites: the Facebook case. Computers in Human Behavior, 53, 102-110. https://doi.org/ 10.1016/j.chb.2015.06.045.

Nix, G. A., Ryan, R. M., Manly, J. B., \& Deci, E. L. (1999). Revitalization through self-regulation: The effects of autonomous and controlled motivation on happiness and vitality. Journal of experimental social psychology, 35(3), 266-284.

Nunnally, J. C. (1978). Psychometric Theory. New York, NY: McGrawHill.

Pelletier, L. G., Tuson, K. M., Fortier, M. S., Vallerand, R. J., Briere, N. M., \& Blais, M. R. (1995). Toward a new measure of intrinsic motivation, extrinsic motivation, and amotivation in sports: The Sport Motivation Scale (SMS). Journal of sport and Exercise Psychology, 17(1), 35-53.
Pihlström, M., \& Brush, G. J. (2008). Comparing the perceived value of information and entertainment mobile services. Psychology \& Marketing, 25(8), 732-755.

Putrevu, S., \& Lord, K. R. (1994). Comparative and noncomparative advertising: Attitudinal effects under cognitive and affective involvement conditions. Journal of Advertising, 23(2), 77-91.

Qin, L., Kim, Y., \& Tan, X. (2016). Understanding the intention of using mobile social networking apps.

Rajala, R., \& Westerlund, M. (2010, January). Antecedents to consumers' acceptance of mobile advertisements-A hierarchical construct PLS structural equation model. In 2010 43rd Hawaii International Conference on System Sciences (pp. 1-10). IEEE.

Reeve, J. (1989). The interest-enjoyment distinction in intrinsic motivation. Motivation and emotion, 13(2), 83-103.

Reis, H. T. (1994). Domains of experience: Investigating relationship processes from three perspectives. Theoretical frameworks for personal relationships, 87-110.

Shankar, V., Venkatesh, A., Hofacker, C., \& Naik, P. (2010). Mobile marketing in the retailing environment: current insights and future research avenues. Journal of interactive marketing, 24(2), 111-120.

Sinkovics, R. R., Pezderka, N., \& Haghirian, P. (2012). Determinants of consumer perceptions toward mobile advertising - a comparison between Japan and Austria. Journal of Interactive Marketing, 26(1), 21-32.

Sledgianowski, D., \& Kulviwat, S. (2009). Using social network sites: The effects of playfulness, critical mass and trust in a hedonic context. Journal of Computer Information Systems, 49, 74-83.

Solomon, M. R. (2004). Consumer behaviour: buying, having and being (6th eds).

Stewart, D. W., \& Pavlou, P. A. (2002). From consumer response to active consumer: Measuring the effectiveness of interactive media. Journal of the Academy of Marketing Science, 30(4), 376-396.

Şimșek, G. (2013). Kișisel mecralarda reklam yayını: Kișilerin sosyal medyada reklam paylaşım motivasyonları. Akademik Incelemeler Dergisi (AID), 8(3), 213-239.

Teo, T. S. H., Lim, V. K. G., \& Lai, R. Y. C. (1999). Intrinsic and extrinsic motivation in Internet usage. Omega: International Journal of Management Science, 27, 25-37

Ünsal, Y. (1984). Bilimsel Reklamcıllk ve Pazarlamadaki Yeri. İstanbul: Tivi.

Vallerand, R. J., \& Blssonnette, R. (1992). Intrinsic, extrinsic, and amotivational styles as predictors of behavior: A prospective study. Journal of personality, 60(3), 599-620.

van der Heijden, H. (2004). User acceptance of hedonic information systems. MIS Quarterly, 28, 695-704.

Wu, J., \& Lu, X. (2013). Effects of extrinsic and intrinsic motivators on using utilitarian, hedonic, and dual-purposed information systems: A meta-analysis. Journal of the Association for Information Systems, 14(3), 1.

$\mathrm{Xu}, \mathrm{D}$. J. (2006). The influence of personalization in affecting consumer attitudes toward mobile advertising in China. Journal of computer information systems, 47(2), 9-19.

Yazıcıŏlu, Y., \& Erdoğan, S. (2004). SPSS uygulamalı bilimsel araştırma yöntemleri. Detay Yayıncılık, Ankara, (s 53).

Zikmund, W. G. (1997). Business Research Methods, 5. Edition, The Dryden Press, Orlando. 